症 例

集学的治療にて根治した晚期再発性進行性精巣腫瘍の 1 例

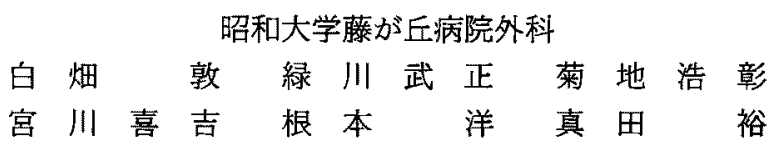

精巣腫瘍の診断にて, 除辠術を施行し15年後に後腹膜に晚期再発をした embryonal carcinoma の 1 例を経験したので報告する，症例は30歳，主訴は腹部腫瘦で1996年，12 月当院外来を受診した，1981年に精巣腫惶の診断で除殬術を施行し，病理診断は embryonal carcinoma であった。来院時, 腹部腫溜は直径 $50 \mathrm{~mm}$ で下大静脈浸潤を誌め, 血清 AFP は7, 200ng/d と異常高值であった. 入院後, 全身化学療法, 放射線療法, 外科 的腫瘍摘出術 (下大静眽合併切除) を組み合わせた集学的治療を施行し, 睡場マーカー は術後 2 力月で正常範囲内になった。術後 7 年経過した現在でも再発兆候は認めていな い.

索引用語：集学的治療, 晚期再発, embryonal carcinoma

\section{緒 言}

embryonal carcinoma は多くは無痛性の腫瘤とし て発見されることが多い。中でも圅丸の腫瘤として発 見される以前に, 鎖骨上裔, 後腹膜リンバ節への転移 が見つかることが少なくない.本稿では他院にて鋅丸 摘出術が施行され，術後15年後晚発性再発をきたした embryonal carcinoma の 1 例に対し幹細胞移植併用 大量化学療法および放射線療法を行い, 腫瘤の縮小と 待機的な完全腫瘤切除を行い得た 1 例を経験したので 若干の文献的考察を加えて報告する.

症例

患者：30歳, 男性.

主訴：腹部腫瘤。

既往歴：17歳，右辠丸腫瘍にて辡丸摘出術施行．病 理所見は embryonal carcinoma (一部は奇形腫)であ った.

家族歴：特記すべき事項なし。

現病歴: 平成 8 年12月, 背部痛のため近医受診し, 腹部 CT にて後腹膜に直径 $50 \mathrm{~mm}$ の腫留を指摘され, 精查加療目的にて平成 9 年 1 月当科入院となる.

入院時現症：身長 $173 \mathrm{~cm}$, 体重 $63 \mathrm{~kg}$, 体温 $36.8^{\circ} \mathrm{C}$,

2004年 1月27日受付 2004 年 5 月14日採用

〈所属施設住所〉

テ227-8501 横浜市青葉区藤が丘 1-30
血圧 $120 / 60 \mathrm{mmHg}$, 眽拍72回/分·整, 眼瞼結膜貧血な し, 眼球結膜黄疸なし. 腹部身体所見ては腹部右側に 鷄卵大の腫瘤を触知した。また，右下腹部に手術洀痕 を認めた。

入院時検查成績: 血液一般検査では異常は認めなか った。生化学検査では BUN $23 \mathrm{mg} / \mathrm{dl}$, Cre 1.3mg/dl と軽度腎機能低下を示した。腫場マーカーでは AFP $7,200 \mathrm{ng} / \mathrm{dl}$ (当院正常基準 $20 \mathrm{ng} / \mathrm{ml}$ 以下) と異常高値 を示した.

腹部造影 CT 検查：右上腹部に境界明瞙で周囲に造 影効果を認め，内部 low density な長径 $50 \mathrm{~mm}$ の腫瘦 を認めた。同時に下大静脈への浸潤が強く疑われた (図 1 ).

腹部 MRI 検查 : 腹部矢状に後腹膜より腹膜を圧排 する T 1 強調像で high intensity な50mm 大の腫癐を 想めた（図2).

腎孟尿管造影検查：腫瘤により右尿管が著明に圧排 され，尿管壁の辺縁不整所見が認められた（図 3 ).

下大静脈造影検查: 第 3 腰椎レベルで腫瘤により $100 \mathrm{~mm}$ にわたり著明な圧排狭窄を認め,下大静脈浸潤 が強く疑われた（図4).

以上より，後腹膜に晚発性再発をきたした embryonal carcinoma と診断した。 また, 入院後諸検查 にて, 下大静脈浸潤，リンパ節転移が強く疑われたた め，化学療法，放射線療法を含めた集学的治療を先行 


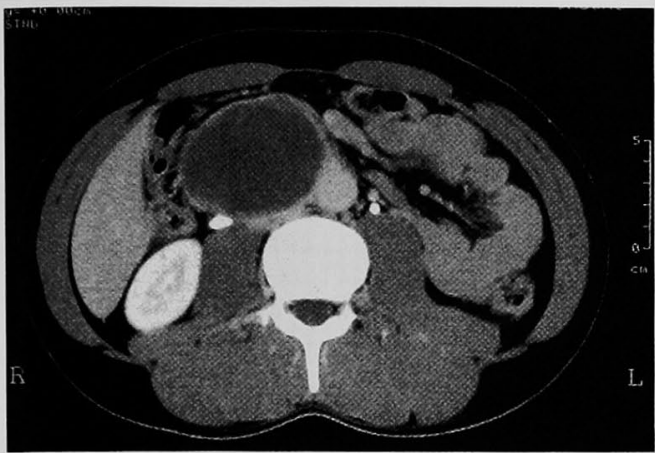

図 1 入院時腹部 $\mathrm{CT}$ ：右上腹部に境界明瞭で周囲に造 影効果を認め, 内部低吸収域な長径 $50 \mathrm{~mm}$ の腫瘤を認 めた。

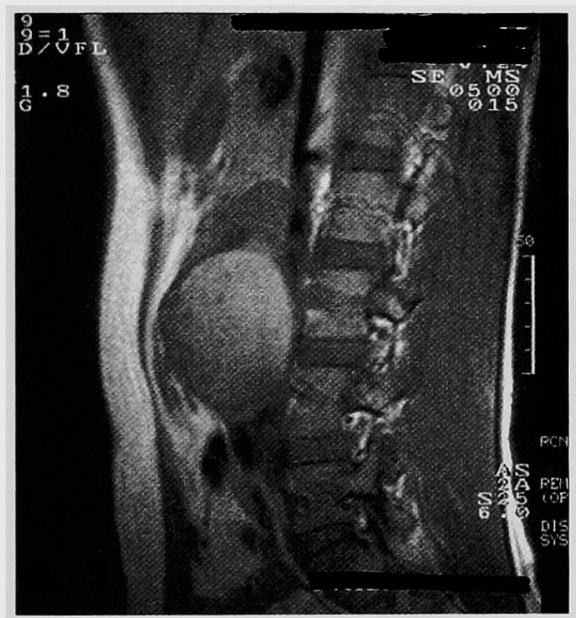

図 2 入院時 MRI 検査: 後腹膜より腹膜を圧 迫する高信号域の腫瘤を認めた。

させ,その後に外科的切除を予定した. 初回化学療法 として BEP 療法 (Cisplatin $20 \mathrm{mg} / \mathrm{m}^{2} /$ day, day 1 $\sim 5$, : Etoposide $100 \mathrm{mg} / \mathrm{m}^{2} /$ day, day $1 \sim 5$, : Bleomycin 30mg/body/day, day 1，9，16, ) を計 2 クールを施行し, second-line として VeIP 療法 (Cisplatin $20 \mathrm{mg} / \mathrm{m}^{2} /$ day, day $1 \sim 5$, : Vinblastine $0,11 \mathrm{mg} / \mathrm{kg} /$ day, day $1 \sim 2$, : Ifosfamide $1,2 \mathrm{~g} /$ $\mathrm{m}^{2} /$ day, day $1 \sim 5$, ) を参考にし Aqupla $(35 \mathrm{mg}$ / body/day, day $1 \sim 5$, ), Ifosfamide ( $2,5 \mathrm{~g} /$ body/ day, day $1 \sim 5$,) を1クール施行した. しかし, い ずれも IR（治療抵抗性）であり third line の salvage 化学療法として, 末梢血幹細胞移植を併用した超大量

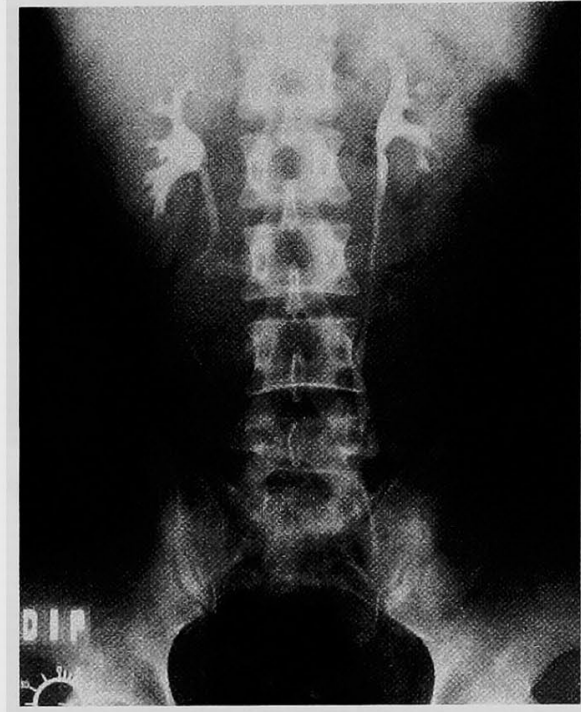

図 3 入院時腎盃尿管造影：腫瘤により尿管が 著明に圧迫され，尿管壁の辺縁不整所見が認め られた。

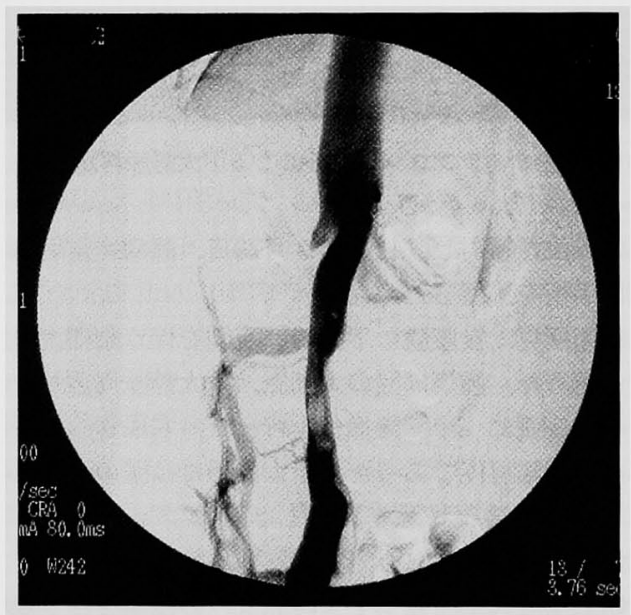

図4 下大静脈造影：第 3 腰椎レベルで腫瘤により $100 \mathrm{~mm}$ にわたり著明な圧迫狭窄を認めた。

化学療法 Carboplatin (850mg/body/day, day 1,3 , 5 ,) Etoposide (680mg/body/day, day 1, 3, 5,) を 1 クール施行したが IR であった. 化学療法施行後, $2 \mathrm{~Gy} /$ 回で計48Gy の放射線療法を施行した．その結 果, 放射線療法が著効し AFP が7,200ng $/ \mathrm{ml}$ から $5,200 \mathrm{ng} / \mathrm{ml}$ と著明な低下を示した。腹部 CT 検查で は最大計で $20 \mathrm{~mm}$ の縮小効果が認められた。待機的外 


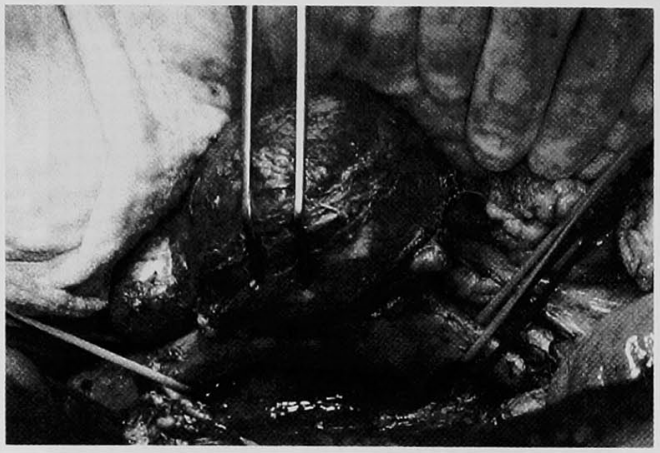

図 5 術中所見 : 下大静脈に浸潤した径 $50 \mathrm{~mm}$ の腫瘍を 認めた。

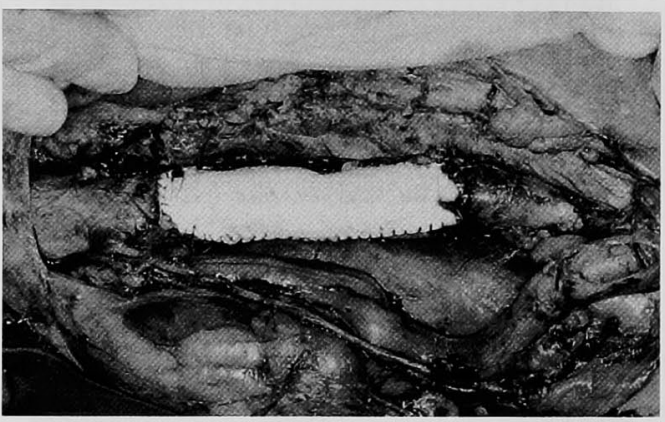

図6 テフロンパッチによる下大静脈再建

科的治療を検討し，1997年 9 月29日，腫瘤完全切除目 的に手術を施行した。

手術所見：後腹膜に下大静脈浸潤を伴う鵎卵大の腫 瘤を認めた。腫瘍周囲の大動脈, 下大静脈周辺リンパ 節を腫場側につけ剝離操作を行った，右尿管への浸潤 はなく剶離可能であった。下大静脈には壁の一部に浸 潤がみられ合併切除を施行しテフロン patchによる 下大静脈再建を行った（図 5, 6).

切除標本肉眼所見：下大静脈壁への浸潤を伴う鶏卵 大の腫瘤で割面は出血，壊死を伴い多様な様相を示し ていた（図 7).

病理組織学的所見：摘出標本の大部分は壊死し，弱

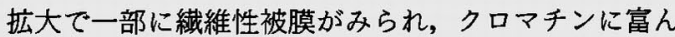
だ，乳頭状・管腔状の高分化異型性を認めた。強拡大 では高度な核分裂像を認めた。病理学的に embryonal carcinomaに特徴的な像を示した。なお， surgical margin は腫崵細胞陰性であった（図 8).

術後経過：術後第60病日で合併症なく退院した。術 後化学療法は本人の希望により施行していない. 術後

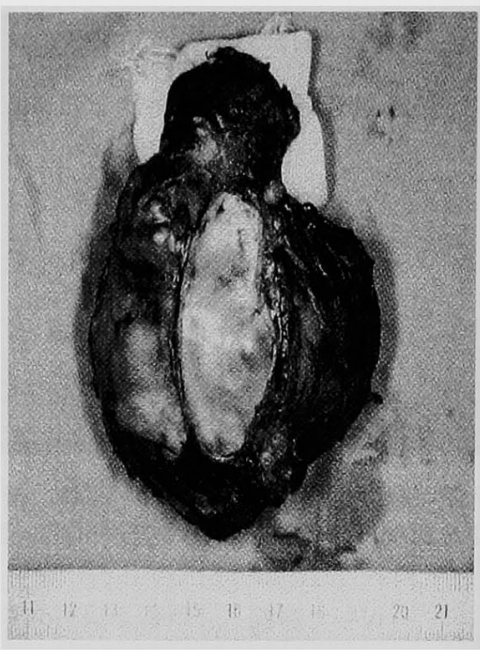

図 7 摘出標本：下大静脈への浸潤を伴 う鷄卵大の腫瘤で割面は出血，壊死を 伴っていた.

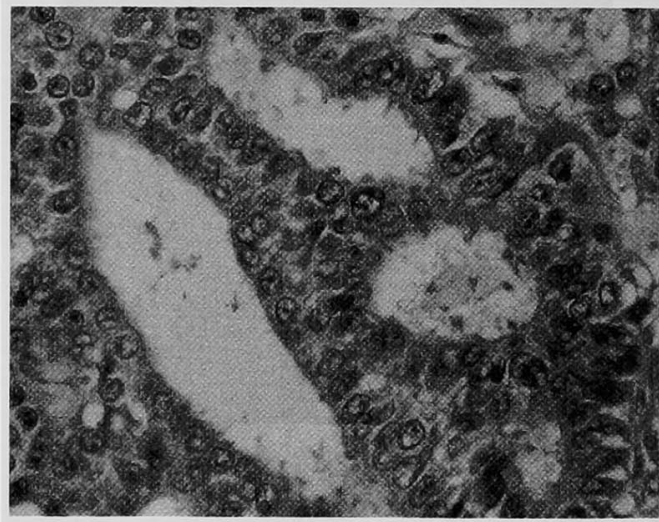

图 8 病理所見 $(\mathrm{H}-\mathrm{E}, \times 40)$ ：一部瀻維性被膜に覆わ れ,クロマチンに富んだ乳頭状, 管腔状の高分化異型性 を認めた

2 カ月で AFP 7.3ng/dl と著明に低下し，2004年 2 月 には AFP 5.0ng/dl と正常範囲を示し, 画像診断にて 再発兆候は認めていない。

\section{考 察}

胎児性癌 embryonal carcinoma は辠丸胚細胞腫瘍 としてはセミノーマに次いで頻度が高く，単一組織型 としても存在するが複合型もしくは混合型胎児性癌の 一成分として最も頻度が高い. 好発年齢は30歳代でセ ミノーマよりも10歳程若い年齢に生じる，高齢者では 
表 1 精栄腫瘦の予後不良因子

\begin{tabular}{|c|c|}
\hline $\begin{array}{l}\text { 進行期の腹 } \\
\text { 部病変 }\end{array}$ & $\begin{array}{l}\text { 触知可能病変 }(+) \text {, 腄瘍 } 10 \mathrm{~cm} \text { 以上, 肝 } \\
\text { 転移 }(+)\end{array}$ \\
\hline $\begin{array}{l}\text { 進行期の肺 } \\
\text { 病変 }\end{array}$ & $\begin{array}{l}\text { 各肺野 } 10 \text { 個以上の多発転移 }(+) \text {, 最大 } \\
\text { 転移巣径 } 3 \mathrm{~cm}\end{array}$ \\
\hline 多蔵器病変 & 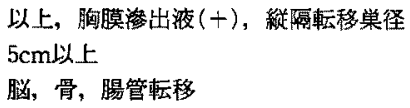 \\
\hline $\begin{array}{l}\text { 腫 湯マー } \\
\text { カー }\end{array}$ & $\mathrm{LDH}, \beta-\mathrm{hCG}, \mathrm{AFP}$ 著明な上昇 \\
\hline 組織型 & 緁毛癌, 性腺外胚細胞腫瘍 \\
\hline
\end{tabular}

(Javadpourによる)

稀であるが86歳で発症したとの報告もなされ，化学療 法に対する感受性が高いといわれている゙.

自験例のように長期寛解後 15 年での後晚期再発する 機序は現在不明であるといわざるを得ない．第1亿初 診時に既に遠隔リンパ節転移への転移がみられ，15年 にもわたり dormant cell として生き残り, 再増殖した 可能性が考えられる. 第 2 亿, 種々のウイルス感染な どによりそれまで腫擅細胞の增殖を抑制していた免疫 細胞の機能が低下，または成人への移行期で内分泌系 の変化により腫湟免疫系への変調をきたし腫場細胞の 増殖をきたしたとも推測される゙。このような晩期再 発精巣腫湟に与ける 2 年間寛解後晚期再発率は $3 \%$ で，長くて32年後再発が報告されている．晚期再発例 にでは化学療法抵抗性のため手術治療が推奖されてい $\Xi^{334)}$.

右睪丸原発の場合, 同側辠丸原発や左辜丸原発と比 较し，転移による inferior vena cava obstruction (IVCO) の頻度が高くなり， $5 \mathrm{~cm}$ 以上の paracaval abdominal mass では高率に合併し, retroperitoneal primary tumor では少ない，症状は無症状が多いが， 腹壁静脈怒張, 下肢浮腫, 深部静脈血栓症など多彩な 症状を引き起こし抗凝固寮法が罗励されているが, metal stent 插入や, 右心系まで及んだ症例に対して手 術療法を施行した報告もあるが治療法は確立していな ( ${ }^{5) 6)}$. 自験例は右睪丸原発で $5 \mathrm{~cm}$ の下大静脈浸潤を 伴う paracaval abdominal mass がありテフロン patch を用いた下大静眽合併切除を施行した. Surgical margin は陰性で再発, 術後合併症は無く経過良好 であった。 下大静脈再建は肝臓外科領域にでは，肝下 部下大静脈一右心房間の passive bypass，体外㯰環や バイオポンプを用いた Active V-V シャント補助下に
抢ける，人工血管，臍静脈，腹膜，切除肝中肝静脈， 自家心䨖膜などを用いた再建が報告されているが， embryonal carcinoma の後腹膜転移症例に対してテ フロンpatch を用いた下大静脈合併切除の報告はな (1) 7899 .

Embryonal carcinoma では血清 AFP 值, $\beta-\mathrm{HCG}$ 值扔よび LDH 值が血清腫崵マーカーとして確立して いるが，ど扎も特異的ではなく，CA19-9值は non seminomatous germ cell tumors (NSGCT) で有意 に高く, 組織型では embryonal carcinoma 扔よび yolk sac tumor 含む症例で有意に血清值が高いた め, 血清 AFP $\beta$-HCG と combination assay を行 うことにより組織型の推測に有用である。また, CA19 -9は臨床病期および予後との相関は認めないが，治療 経過や腫湯の進行に伴い血清值が推移するため経過観 察に有用であるとされている5).

NSGCT に対する化学療法は1980年代初頭にわが国 でも cisplatin が使用できるようになり，現在でも精巣 腫瘍の完治は一部の難治性の症例を除き，多郕併用化 学療法により70〜80\%で根治がみられるようになっ た。しかし，予後不良因子（表 1 ）を有する症例や, 化学療法に抵抗性を示す症例では根治し難いことも多 $い^{10)}$. 本来, 精巣腫場は非常に悪性度の高い腫場であ り, 現在でも ABMT (autologous bone marrow transplantation) p PBSCT (peripheral blood stem cell transplantation）を併用した超大量化学療法の試み は, second-line 以降の salvage 化療法として前治療 でIRであったり前治療後再発した，いわゆる refractory germ cell tumor に対して行われている。最近で はこの他，臨床病期分類 International Germ Cell Cancer Collaborative Group (IGCCCG) poor risk 群 の初回あるいは早期の治療としても検討されるように なっだ!超大量化学療法の効果は, 幾つかの risk factor (絴隔原発, cisplatin を含む chemotherapy $\mathrm{K}$ 対して無反応症例, 'induction chemotherapy 前 $\beta$ HCG 值など）によって左右され，またGoodまたは Intermediate Risk では $\left[{ }^{18} \mathrm{~F}\right]$ FDG PET $\left(\left[{ }^{18} \mathrm{~F}\right]\right.$ fluorodeoxyglucose positron emission tomography) が効 果予測に有用であると報告されている ${ }^{12)-15}$. しかし現 在でも超大量化学療法は, third-line として難治性, 再 発例に施行しても10 30\%の症例にしか反応が得られ ていないが, 難治性精巣腫湐の切り札となるべく期待 されている.したがって, 超大量化学療法の適応は併 用する抗癌剤の種類や用量など今後重要な検討課題で 
ある。

自験例は IGCCCで Poor Risk 群で予後不良因子を 有し 5 年生存率は $48 \%$ と報告されている症例であるた め, 積極的な集学的治療を施行した。なお， salvage chemotherapy 後の化学療法は無効と報告され, 自験 例においても術後化学療法は施行していない。また， 一般的に NSGCT は放射線感受性が悪いといわれ自 験例のような症例に集学的治療の一環として放射線療 法を施行し，AFPの低下と畽瘍の縮小した報告は無 く, NSGCT に対する集学的治療の一つとしての放射 線療法の見直しが今後必要上おもわれる。2004年 2 月 現在も再発の兆候を認めておらず，精单腫湯において は，他の固形癌と異なり，進行症例であっても完全宽

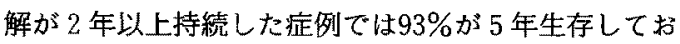
り，自噃例も根治しえたものと考えられる。

\section{結 語}

IGCCCG Poor Risk 群の embryonal carcinoma に 対して集学的治療によって根治しえた症例を経験した ので若干の考察を加えて報告した。

\section{文献}

1) Gouji $K$, Watsuji $T$, Ubai $T$, et al: Embryonal carcinoma of the testis associated with pros. tate cancer in a 72-year-old man. Int J Urol 8 : 719-721, 2001

2）䟠谷 温：副等原発摘出 10 年後に頭蓋内に再発し た神経茅腫. 小児外科 $29: 731-736 ， 1997$

3) Michael H, Lucia J, Foster RS, et al: The Pathology of Late Recurrence of Testicular Germ Cell Tumors. The American Journal of Surgical Pathology $24: 257-273,2000$

4) Baniel J, Foster RS, Gonin R, et al: Late Relapse of Testicular Cancer. Journal of Clini. cal Oncology 13 : 1170-1176, 1995

5）鉿木一実, 徳江章彦: 綪单肧細胞埂場における血 清 CA19-9の測定意義についての㭘討. 泌紀 47:467-472, 2001

6) Hasan B, Tung K, Weeks R, et al : The Management of Inferior Vena Cava Obstruction
Complicating Metastatic Germ Cell Tumors. Cancer 85 : 912-918, 1999

7）紀野修一，葛西眞一，石崎，彰他：肝下部下大静 眽一右心房間の passive bypass を用いた下大静 脈再建を伴亏肝切除. 手術 $55 ： 805-812 ， 2001$

8）田代征記, 三宅秀則, 安藤 勤：Active V-Vシャ ント法. 手術 55：797-804，2001

9）窪田敬一, 幕内雅敏, 高山忠利他: 拡大肝右葉切 除十下大静脈合併切除後切除肝中肝静脈を用いた 下大静脈再建法。手術 52：1259-1262，1998

10) Javadpour $N$ : The role of biologic tumor markers in testicular cancer. Cancer $45: 1755$ $-1761,1980$

11) The International Germ Cell Cancer Collaborative Group : International germ cell consensus classification: a prognostic factor-based stag. ing system for metastatic germ cell cancers. J Clin Oncol 15: 594-603, 1997

12) Broun ER, Nichols $C R$, Kneebone $P$, et al: Long-term outcome of patients with relapsed and refractory germ cell tumors treated with high-dose chemotherapy and autologous bone marrow rescue. Ann Intern Med 117 : 124-128, 1992

13) Beyer $D$, Kingreen $D$, Krause $M$, et al : Long term survival of patients with recurrent or refractory germ cell tumors after high-dose chemotherapy. Cancer 79:161-168, 1997

14) Koshida K, Katou H, Mizokami A, et al : High -dose chemotherapy wih peripheral blood stem cell transplantation for advanced testicular cancer. Int J Urol $9: 146-153,2002$

15) Bokemeyer $C$, Kollmannsberger $C$, Oechsle $K$, et al : Early prediction of treatment response to high-dose salvage chemotherapy in patients with relapsed germ cell cancer using $\left[{ }^{18} \mathrm{~F}\right]$ FDG PET. British Journal of Cancer $86: 506-511$, 2002 


\title{
A CASE OF EMBRYONAL CARCINOMA WITH LATE RETROPERITONEAL RECURRENCE 15 YEARS AFTER ORCHIECTOMY
}

\author{
Atsushi SHIRAHATA, Takemasa MIDORIKAWA, Hiroaki KIKUCHI, \\ Kiyoshi MIYAKAWA, Hiroshi NEMOTO and Yutaka SANADA \\ Department of Surgery, Showa University Fujigaoka Hospital
}

\begin{abstract}
A 30-year-old man with advanced embryonal carcinoma and late retroperitoneal recurrence 15 years after orchiectomy was addmitted for an abdominal mass ( $50 \mathrm{~mm}$ diameter) in December 1996. He had undergone orchiectomy for embryonal carcinoma of the right testis. He had retroperitoneal tumor with inferior vena cava obstruction. Serum $\alpha$-fetoprotein was elevated to $7200 \mathrm{ng} / \mathrm{dl}$. He underwent multidisciplinary treatment consisting of systemic chemotherapy, radiation, and surgical tumor excision with partial inferior vena cava resection. The efficacy of combined treatment normalized tumor markers within 2 months and maintained complete serological remission 7 year after combination therapy.
\end{abstract}

